\title{
Pandemic Coronavirus Issue: How do We Respond?
}

\author{
Asim Kurjak
}

Journal of South Asian Federation of Obstetrics and Gynaecology (2020): 10.5005/jp-journals-10006-1747

The International Academy of Perinatal Medicine has a remarkable past and I sincerely believe a brilliant future. ${ }^{1}$ Naturally, the future depends on role of its members because no academy can be appreciated by itself but by the reputation of each and all its members. From the time of Plato, the academy has been an institution of highest intellectual authorities, the most creative and productive members of the society. Indeed, science is true global activity because its very nature is global. Most of us welcomed the positive globalization process but with the recent pandemic of corona disease we are introducing the negative part of globalization with many unpredictable developments. ${ }^{2}$ In science, we do not have good and bad work. By following our principal duties, we justifiably expect that creative and visionary members of the academy show again its intellectual power in order to solve this global pandemic. The future relies on the past and it is just proper time to show our own vision on the future and situation after pandemic is over. ${ }^{3}$

Our academy has both the responsibility and privilege to conduct scientific research on the impact of coronavirus disease 2019 (COVID-19) pandemic on maternal, fetal, and neonatal health. Recently published studies in prestigious journals are unfortunately of very suspicious quality, and the results of the studies give not only little additional information for healthcare providers but also cause confusion with inappropriate adjustments of the antenatal care without scientific background.

Without any doubt, this will open up again new visionary solutions and one of them will be a deep analysis of what science in perinatal medicine did assess and what is recommended to the perinatal world. ${ }^{4,5}$ In a world of rapid advances in scientific discovery with an unprecedented insight and understanding of human development, which are reshaping the meaning and value of human existence, it is clear that we all are living in a global setting with PC-based videoconferencing and satellite transmission. Therefore, the new idea born in a small global village will soon be available at each corner of the world.

We are lucky to have our official Journal of Perinatal Medicine and the academy corner in it dedicated to wise thoughts of academy members. What should we really offer through the journal and its academy corner to our readers in this complicated part of our lives? $?^{5,6}$

\section{Which Recent Scientific News is Worth Paying Attention To?}

First, it should be stated that most of the scientific research on COVID-19 (also during pregnancy) is currently being conducted in a way that would probably be completely unacceptable to serious science in any other circumstances. The research has been published fast-tracked and possibly without a proper peerreview process, using small and often insufficiently representative samples, and numerous imperfections in the research design are
International Academy of Perinatal Medicine, Zagreb, Croatia; Sarajevo School of Science and Technology, Zagreb, Croatia

Corresponding Author: Asim Kurjak, International Academy of Perinatal Medicine, Zagreb, Croatia; Sarajevo School of Science and Technology, Zagreb, Croatia, e-mail: asim.kurjak@public.carnet.hr

How to cite this article: Kurjak A. Pandemic Coronavirus Issue: How do We Respond? J South Asian Feder Obst Gynae 2020;12(1):5-6.

Source of support: Nil

Conflict of interest: None

being overlooked as well as many other details that are usually taken into account. All these factors have resulted in a flood of superficial research, all in a desire to get answers as fast as possible. Unfortunately, rush and wrong answers can cause greater damage than an accurate but slow one. An additional problem is that every single research is getting huge media attention worldwide, with an increasing number of published preprint results-results of scientific papers that anyone can publish on prepublication platforms, without any serious scientific or professional review. Scientists will have no trouble distinguishing serious research from those with serious flaws but journalists will have a harder time making that distinction. Thus, it is realistic to expect a whole series of daily reports on various "scientific research results," which will in a week or two turn out to be wrong or unfounded. It is a shame that so much time and media space are constantly being wasted on completely unfounded reports and results. But that is one of the fundamental characteristics of this "infodemic" we're experiencing.

\section{Good News and Bad News}

As an illustration, we will review some most important open questions and scientific insights mentioned in the media in the past weeks and which are worth following in the near future. At the moment, some scientific news seems very unfavorable in terms of fighting COVID-19, but they require significant further research. It appears that the virus can reemerge and again become detectable in patients who recovered and had tested negative. This is being thoroughly questioned now, because it's possible that the tests aren't reliable enough or that the virus takes a lot longer to be eliminated from the body. However, if it turns out that recovered patients can become reinfected that soon, this would be very bad news. It would mean that the immunity achieved against the novel coronavirus is not permanent, as well as that the vaccine might not be as effective as we had hoped. But it is still too soon to draw such conclusions; we need to wait for a new larger-scope research. Furthermore, it is less and less likely that the virus will fade with the coming warm weather, because the newest data from western Africa and other warm and humid countries show that the 
virus continues to successfully spread. When a larger number of countries achieve a significant reduction in the number of deaths and new cases, there will be very few countries willing to open their borders without imposing a 2-week isolation for everyone entering. This will make international travel in the coming months significantly difficult, so it is reasonable to expect that the coming tourist season will mostly cater to domestic tourists, and only if we succeed in avoiding a second quarantine. Foreign tourists are fairly unlikely at this point, but we should allow for the possibility that things might change in the coming weeks and positively affect the current pessimistic projections. More bad news is that the antiviral medication lopinavir, a protease inhibitor combined with ritonavir for an effective treatment against the HIV virus that causes AIDS, has against all hope shown little to no benefit in treating COVID-19.

However, there is some positive news as well. The comparison of data from China, Italy, Spain, and the United States so far shows that the novel coronavirus hasn't mutated in the sense of increased "death rate" or "spread coefficient," but that its genome is more stable than that of the influenza virus. Also, there are first indications, which have yet to be scientifically confirmed, that the blood plasma transfusions from patients recovered from COVID19 could provide hope for severely ill patients by increasing their levels of circulating early-response antibodies. But it will require significantly more research of a much larger scope before such recommendations could be made, although they make sense from a scientific point of view.

But prevention is the best cure for the new coronavirus disease. At the moment, the world is fighting the virus by old epidemiological methods that have been shown to be effective if introduced in a timely manner and strictly followed. The vaccine is the hope in the fight with this unpredictable and yet not well-known enemy.
The investigation on the development of the vaccine is going on and still, there are many unanswered questions with hardly any answers. Hopefully, the new coronavirus is not the first unknown microorganism that mankind has been confronted with. We were successful in fighting with unknown microorganisms before and we are convinced that this will be the case with the COVID-19 virus as well. We have to be persistent and optimistic!

The principle of the academy should not be: "any information is better than none." The information should be feasible, usable, and implementable and proven according to the best scientific principles. It may be that the research of the members of the academy will not be the first to be published, but we certainly aim that the scientific evidence published by the academy will be the best one.

\section{References}

1. Kurjak A. First 10 years of the international academy of perinatal medicine - which lessons we have learned and what are future challenges (academy corner). J Perinat Med 2016;44(7):733-735. DOI: 10.1515/jpm-2016-0018.

2. Kurjak A, Di Renzo GC, Stanojevic M. Globalization and perinatal medicine - how do we respond? J Matern Fetal Neonatal Med 2010;23(4):286-296. DOI: 10.3109/14767050903105889.

3. Kurjak A, Dudenhausen J, Chervenak FA. Editorial: Does globalization and change demand a different kind of perinatal research. J Perinat Med 2008;36(4):273-275. DOI: 10.1515/JPM.2008.068.

4. Kurjak A. Global education in perinatal medicine: will the bureaucracy or smartocracy prevail? (academy corner). J Perinat Med 2014;42(3):269-271. DOI: 10.1515/jpm-2014-0009.

5. Kurjak A. Editorial: 3D/4D sonography. J Perinat Med 2017;45(6): 639-641. DOI: 10.1515/jpm-2016-0431.

6. Kurjak A, Dudenhausen JW. Editorial: poverty and perinatal health. J Perinat Med 2007;35(4):263-265. DOI: 10.1515/JPM.2007.089. 